\title{
失語症の回復過程における左右大脳半球の役割 SPECTを用いた検討
}$$
\text { 三村 將 }
$$

要 約：失語症の回復過程における左右大脳半球の役割という臨床的な立場から, 脳機能画 像と言語機能の問題を検討した。失語症の回復には, 左半球内の機能回復と右半球内の機能活 性化という 2 つ機序が想定されている．実際には両半球を含めた機能的ネットワークの再構 築が関与する可能性が高いが，本論ではまず，失語症の長期回復経過において左右半球が経時 的に異なる役割を果たすことを示唆する自験デー夕を紹介した. SPECT を用いて脳血流量の 変化を検討した 2 つの相補的な実験からは, 発症後早期の言語機能の回復は左半球内の機能的 改善と関連し，一方，その後の長期的な回復には右半球の役割が大きいと推測された.PETや 機能的 MRI を用いて失語症患者に機能賦活を行う最近の研究からも，左右半球の役割が経時 的に異なる可能性が示されている. SPECT は比較的簡便で, 複数回施行するのに適しており, 脳損傷例の経時的な臨床研究を行うには有用である.
\end{abstract}

索引用語 : SPECT, PET, 機能的 MRI(fMRI), 失語症, 回復

\section{Differential Role of Left and Right Hemispheres for Recovery from Aphasia _Evidence from SPECT Studies__}

Masaru Mimura

\begin{abstract}
Language organization and functional neuroimaging was discussed with special interest in the roles of the left and right hemispheres in recovery from aphasia. Two mechanisms have been postulated for the process of language restitution following aphasia; 1) partial recovery of left-hemisphere language-related areas, and 2) activation in their homologous counterparts in the right hemisphere. In fact, functional reorganization of the language network may involve both hemispheres. In this review the results of our two experiments, prospective and retrospective (Mimura et al., 1998), are presented, suggesting a chronologically dissociable contribution of the left and right hemispheres for recovery from aphasia. The complementary results of both experiments suggest that the initial language recovery within the first year post onset may be linked primarily to functional recovery in the dominant hemisphere, while subsequent language recovery and long-term recovery from aphasia may be related to slow and gradual compensatory functional
\end{abstract}

昭和大学医学部精神医学教室：テ 142-8666 東京都品川区旗の台 1-5-8

Department of Neuropsychiatry Showa University School of Medicine : 1-5-8 Hatanodai, Shinagawa-ku, Tokyo 142-8666 E-mail: mimura@med.showa-u.ac.jp

原稿受理：2001 年 2 月 16 日 
activation in the contralateral hemisphere. Recent activation studies using PET and functional MRI, in which activated or compensated areas are directly visible in aphasic patients, have also suggested a time dissociation in the role of left and right hemispheres. SPECT is clinically available in many institutions and suitable for carrying out serial studies. In addition, SPECT data are now analyzable using SPM (Statistical Parametric Mapping). For these reasons, we recommend SPECT for investigating longitudinal clinical issues affecting brain-damaged patients, such as the recovery process from aphasia.

Key words : SPECT, PET, functional MRI (fMRI), aphasia, recovery

\section{はじめに}

本論では臨床的な脳機能画像研究の立場から，失語 症の回復過程に左右大脳半球の果たす役割という視点 を通じて, 脳機能画像と言語機能の問題にアプローチ する. 脳機能画像として，ここでは失語症の長期回復 に関する single photon emission computed tomography（SPECT）の自験データの紹介を中心に述べ，さ らにこの領域に関して近年急速な進展をみせている positron emission tomography (PET) と functional MRI（fMRI）を用いた失語症患者の賦活研究 activation studyについても通覧する. 賦活研究で現在まで に得られている知見を踏まえて自験デー夕を解釈した 上で, 失語症の回復過程と脳機能画像に関する考察と SPECT の有用性について, 若干の考察を述べる.

\section{失語症の回復と言語の神経基盤}

失語症からの回復には, 初期の失語の重症度, 年齢, 性, 病因, 既往歴, 失語症のタイプ, 病巣の位置, 病 巣の大きさなど，種々の要因が関与することが知られ ている ${ }^{11}$. 臨床的な失語症からの回復の機序ないし神 経基盤としては古くから (1). 左半球損傷部位周辺の部 分的機能回復ないし再構築, (2). 対側右半球内におけ る言語領野対照部位の活性化，の 2 つが想定されてい る.この 2 つ仮説に関しては, いずれか一方が正し いというのではなく，おそらくは両者ともに関与して いる可能性が高い2,3).

失語症の回復に左右半球の双方が関与しているとし て, その役割にはいかなる相違があるのであろうか. ここで主にとりあげるのは時間的な差異の問題であ る. 失語症の回復を長期で追った場合, さまざまな経 過をたどると考えられる. 一般には発症から初期, 特 に 3 カ月くらいの間は比較的急速に言語機能の改善が みられる. その後, ほぼプラトーに達し, 回復が停止 する例もあるが,一方, 長期間ゆっくりと年余にわたつ て言語機能の回復を認める例にも実際には多く遭遇す
る.このような失語症の長期の回復パターンについて 検討した臨床報告はいくつか散見されるが,たとえば, 佐野ら ${ }^{4)}$ は病巣と回復経過との関連について, 中心溝 より前方に病巣が限局する症例, 基底核限局病巣例, 視床限局病巣例の失語症状は発症後早期に急速に回復 L, 一方, 後方限局病巣例や広範病巣例, 基底核進展 型病巣例では， 3 年以上の長期にわたり言語症状の回 復を示す症例が少なくないと述べている。また， Naeser $ら^{5}$ は呼称成績や語彙数などは発症から非常 に長い時間を経て有意に回復を示し得るとしている.

それではこれら言語機能の回復と左右半球における 脳機能画像の変化とはどのような関係にあるのであろ うか.この点を明らかにするため, 言語機能の長期回 復と脳機能画像との関連を検討した自験デー夕を示す $\left(\right.$ Mimura $\left.ら^{6)}\right)$. 実験は発症から比較的早期の失語症 の回復についての前方視的・二時点での検討（実験 I ) と, 発症から比較的長い時間が経過した段階での一時 点での後方視的検討（実験 II）とを行った.

\section{実験 I．前方視的研究}

\section{1. 方法}

対象は左中大脳動脈領域の脳血管障害後に生じた右 利き失語症患者 20 人。標準失語症検查（Standard Language Test for Aphasia: SLTA) による言語評 価と脳 SPECTによる脳血流量測定とを発症後平均 3.2 力月（T 1)と 9.2 力月 (T 2)の 2 時点で施行した. SLTA の成績は失語症の全般重症度, 聴覚的理解, 呼 称, 文の復唱, 短文の音読, 読解, 仮名の書き取り, 短文の書き取りの各項目について評価した. SLTA 全 般重症度に関して, T 2 で T 1 より 3 点以上の改善を 示した例を回復良好群，2点以下の例を回復不良群と して, 対象症例を 2 群に分けて検討した. 回復良好群 と回復不良群では年齢, 性, 病因や臨床分類上の失語 型, 動作性 IQ などに差はみられなかった。また, SLTAの重症度に関しても T 1 では差を認めず（良好 群 3.2 ; 不良群 3.3), T 2 の重症度でのみ有意な差 
を認めた（良好群 5.8；不良群 3.4）。

SPECTは $99 \mathrm{mTc}-\mathrm{HMPAO}$ 用いて日立 Gamma-View D model SPECT scanner で撮像した. 平均脳血流量 (mean cerebral blood flow : $\mathrm{mCBF}$ ) 值は Matsuda ら ${ }^{7,8)}$ による Patlak プロット法により 定量した. 左右の半球 $\mathrm{mCBF}$ とともに, 局所 $\mathrm{CBF}$ を 左右の前頭部, 視床, 側頭部, 後頭部を関心領域 (region of interest：ROI）にそれぞれ設定して測定した。解析 は $\mathrm{OM}+70 \mathrm{~mm}$ のスライスで行った.このスライスで は, 前頭部は前頭葉外側面の弁蓋部, 運動前野, 運動 野を含み，側頭部は上側頭回と聴覚領を含んでいると 考えられた ${ }^{9)}$.

\section{2. 結果}

まず, T 1 と T 2 における左右の半球 $\mathrm{mCBF}$ の変化 を回復良好群と回復不良群とに分けて示す (図 1). 全 体に左半球の $\mathrm{mCBF}$ は右半球に比べて有意に低下し ていた。また, 回復不良群では, 左右ともに半球 $\mathrm{mCBF}$ に T 1 と T 2 で差がみられていない.これに対し, 回 復良好群では両側で半球 $\mathrm{mCBF}$ が改善の傾向を示し ているが,ことに左半球の $\mathrm{mCBF}$ の改善は有意であっ た $(\mathrm{p}<.01)$.これを前頭部, 視床, 側頭部, 後頭部の 各 ROI における局所 $\mathrm{CBF}$ の変化としてみた場合, 各 $\mathrm{ROI}$ での明らかな $\mathrm{CBF}$ の変化はみられなかった。
半球 $\mathrm{mCBF}$ の変化と各言語症状の改善との相関を みると, 左側半球 $\mathrm{mCBF}$ は SLTA 重症度 $(r=0.56$, $\mathrm{p}<.05)$, 呼称 $(\mathrm{r}=0.53, \mathrm{p}<.05)$, 短文の書き取り $(\mathrm{r}=$ $0.55, \mathrm{p}<.05)$ それぞれの変化と正の相関を示した. 一方, 右側半球 $\mathrm{mCBF}$ の変化は SLTA 重症度の変化 とは相関せず（ $\mathrm{r}=0.42, \mathrm{p}>.10)$, 他の下位項目に関 しても仮名の書き取り $(\mathrm{r}=0.71, \mathrm{p}<.01)$ 以外は有意 な相関を認めなかった。

\section{実験 II. 後方視的研究}

実験 I の結果からは発症後 1 年以内の失語症の全般 的な回復には同側左半球内の機能的改善が重要であ り, 一方で対側右半球内の機能的代償が早期の言語機 能の回復に果たす役割は二次的であると推測された。 この結論は脳血管障害の発症後, 4 力月の時点での Tokenテストの成績を予測する因子として有用で あったのは発症後 15 日の時点での左半球のグルコー ス代謝であったとする Heiss ら ${ }^{10)}$, 発症後平均 71.4 日 で測定した局所 CBF についてはことに左側で SLTA 全項目の平均正答率と相関が高かったとする横山ら ${ }^{11)}$ による PET の報告とも矛盾しない.しかしながら, 言 語機能の回復における, この左半球の役割はいつまで 持続するのであろうか？長期にわたって左半球のみ
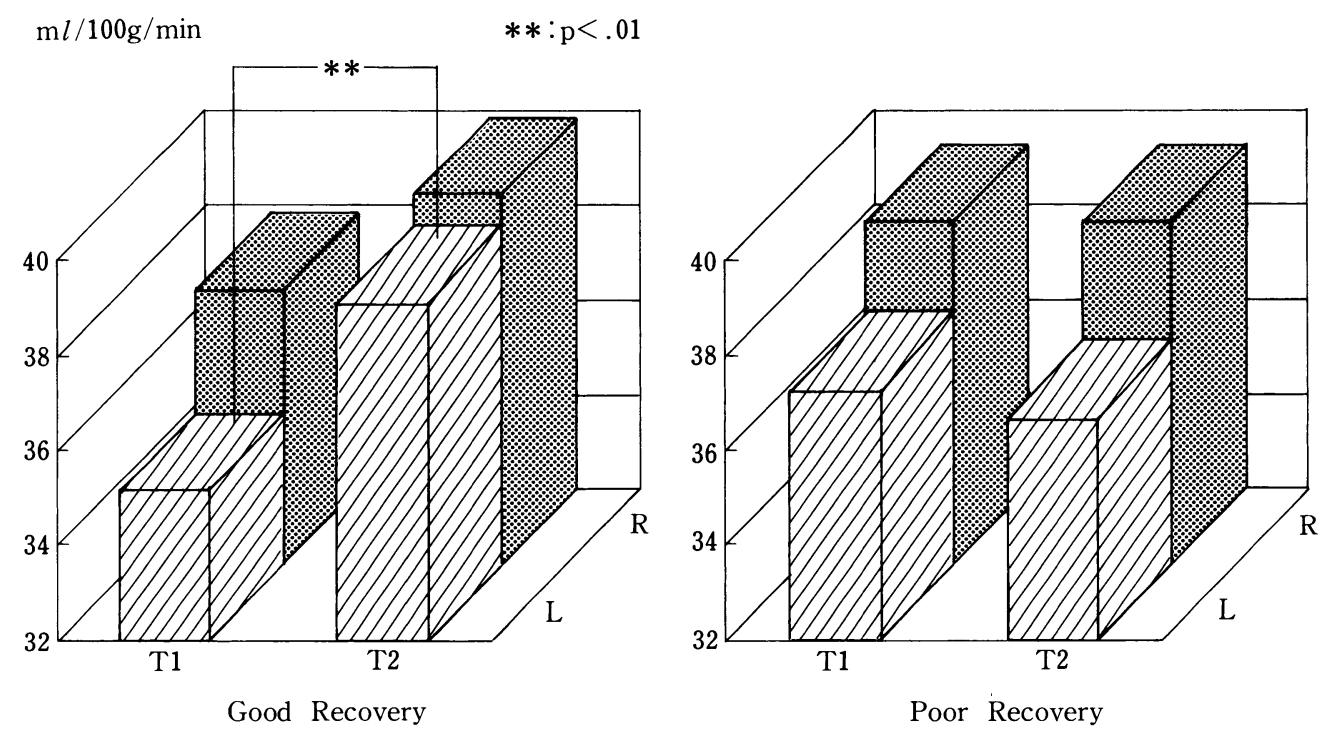

図 1 実験 I （前方視的研究）の結果

発症後平均 3.2 力月 ( T 1) と 9.2 力月（T 2)における左右の半球平均脳血流量を示す．回復不 良群では左右ともに半球 $\mathrm{mCBF}$ に T 1 と T 2 で差がみられないが, 回復良好群では左半球 の $\mathrm{mCBF}$ に有意な改善を認めている 
が関与していくのか，あるいはやがて右半球の機能的 代償が顕在化してくるのであろうか．言語機能の回復 に際して右半球の役割を強調している報告は多い が5,12), この点を長期的な右半球の脳血流改善として認 められるかどうかはよくわかっていない. そこでさら に長期の経過を評価するため，第 2 の実験を行った。

\section{1. 方法}

対象は発症後, 平均 6.9 年を経過した失語症が長期 に残存している右利き患者 16 人. 全例, 左側中大脳動 脈領域の脳血管障害後であり, SLTA による初期言語 評価を発症から平均 6.5 力月後 (Tep) に受けていた. 発症から平均 82.8 力月後 (Tlp) にSLTA による言語 の再評価と SPECT による脳血流量測定を実施した。 なお, 比較のため, 健常対照群 10 人に SPECTを施行 した.SPECT の施行法は実験 1 と同じである.

$\mathrm{Tlp}$ ，すなわち発症から約 7 年の時点での失語症状 の回復の程度から患者を実験 1 と同様に回復良好群と 回復不良群に分けた。Tepに比して TlpでSLTA 重 症度が 3 点以上回復した患者を回復良好群， 2 点以下 の患者を回復不良群に区分した。両群では年齢, 性, 病因や臨床分類上の失語型に大きな差はみられなかっ た。また, SLTAの重症度に関しても Tep では差を認 めず (良好群 2.6 ; 不良群 2.3), Tlp の重症度でのみ 有意な差を認めた（良好群 6.6 ; 不良群 3.2 ).

\section{2. 結果}

$\mathrm{Tlp}$ に扔ける左右の半球 $\mathrm{mCBF}$ を回復良好群と回 復不良群とに分けて示した(図 2 ). 左半球の mCBF は 健常対照群に比べて回復良好群も不良群もいずれも有 意な血流低下を示していた。これに対し，右半球の $\mathrm{mCBF}$ は回復不良群では有意に低下していた一方, 回 復良好群では健常群と同等であった。前頭部における ROI の血流量に関しては，左右ともに健常対照群・回 復良好群に比べて回復不良群の低下が明らかであっ た。また，視床に関しては，左側は良好群・不良群と もに低下しているのに対して，右側では不良群のみ低 下しており，良好群では健常群と同等であった。この 傾向は側頭部でも同様であった（図 3)。すなわち，発 症から約 7 年の長期の経過において最も顕著に認めら れたのは回復良好群と不良群での右半球内の血流改善 傾向の相違であった。

\section{考察}

\section{賦活研究による知見を踏まえて}

以上，失語症の回復経過を SPECT で検討した実験 I, II の結果からは, 早期の言語機能の回復には左半 球内の機能的改善が重要であり, 一方, 右半球も失語

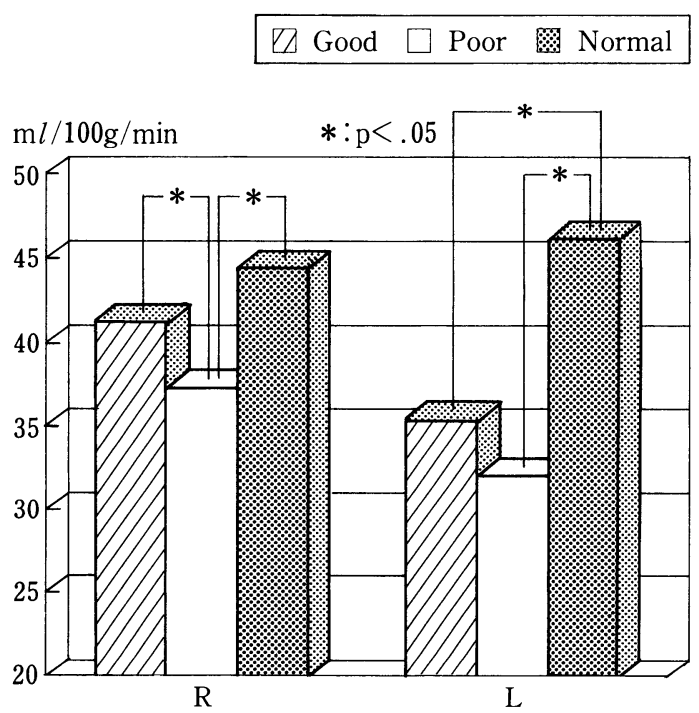

図 2 実験 II（後方視的研究）の結果 発症後平均 82.8 力月 (Tlp) における左右の半 球平均脳血流量を回復良好群と回復不良群と に分けて健常対照群の結果とともに示す

症の回復に重要な役割を演じてはいるが，その代償機 構は長期の経過で遅れてゆっくりと現れてくることが 示唆された.この結論は近年急速に発展している言語 機能の賦活研究の結果からも裏づけられる.もともと 言語の脳基盤に関する検討は損傷例についての神経心 理学的研究と健常者についての賦活機能画像研究とを 合わせる形で進んできた。しかし，ことに 90 年代の半 ばからは損傷例に実際に言語課題を施行して, 機能画 像を撮像する賦活研究が始まり, 失語症の回復過程に おける脳内代償機構をより直接的に検討しょうとする 報告が登場してきている，表 1 亿現時点までに報告さ れている主な失語症患者の賦活機能画像研究をまとめ た ${ }^{13 \sim 28)}$.

これら損傷例の賦活研究は失語症の回復過程での左 右半球の役割についても重要な示唆を与えている，た とえば，Heiss ら ${ }^{20)}$ は失語の回復過程で言語に関連し た機能的ネットワークのなかに階層構造があると考え ている.すなわち, 左上側頭回後部が保たれることが 言語の機能的回復にとって決定的に重要であり, 言語 機能の十分な回復はこの左上側頭回後部が左半球内の 傍シルビウス裂の機能的言語ネットワークに再統合さ れる場合のみに生じるとしている。一方，もしこの左 上側頭回後部が完全に破壊された場合には言語の機能 的回復は困難であるが，この場合まず，左半球内の弁 


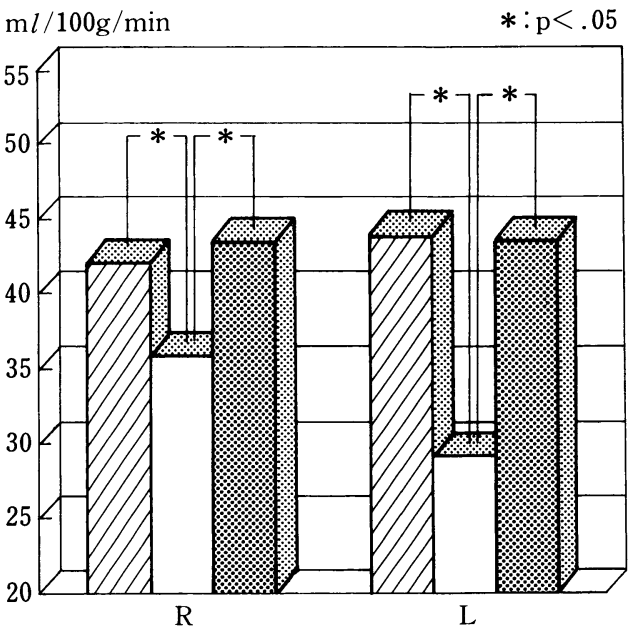

Frontal

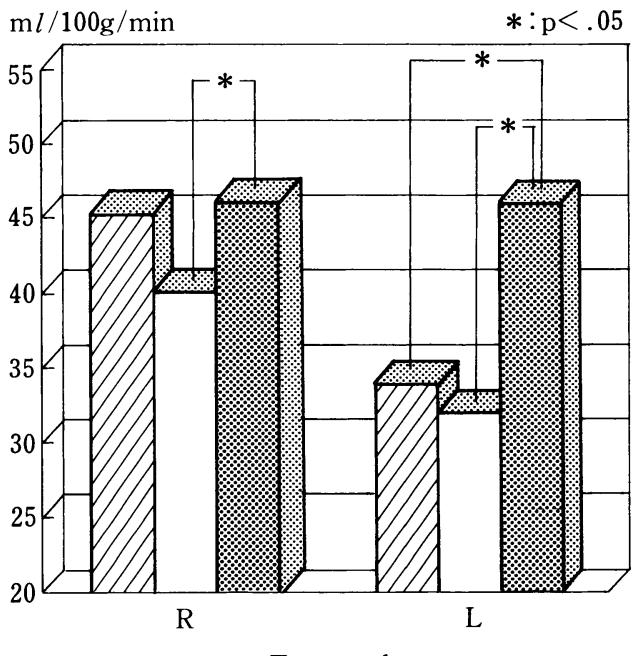

Temporal

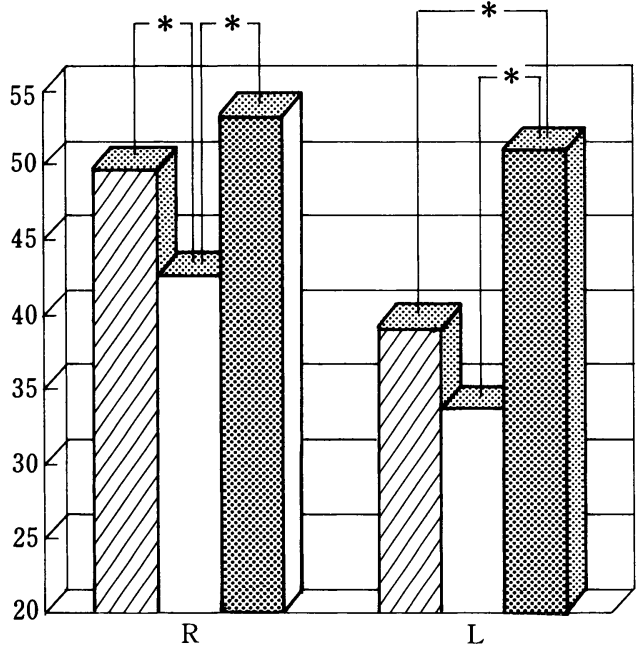

Thalamus

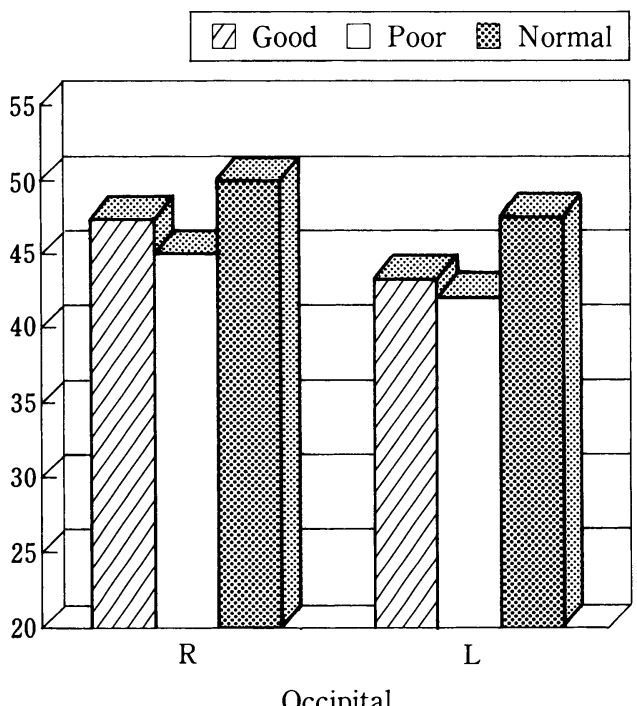

Occipital

図 3 実験 II（後方視的研究）の結果

発症後平均 82.8 力（Tlp）における左右の関心領域（前頭部・視床・側頭部・後頭部）の 局所脳血流量を回復良好群と回復不良群とに分けて健常対照群の結果とともに示す

蓋部や補足運動野などが代償的に賦活され，さらに， 後になって右の上側頭回が動員されてくると考えられ る. 彼らはこのような右半球内の賦活は最後に現れる 代償機構で, また機能的にも十分な回復は見込めない としている.

また, 最近 Rosen ら ${ }^{23)}$ は左下前頭回損傷を有する慢 性期失語症 6 例に PET および fMRI を用いて語幹完 成課題による賦活実験を行い，全例で右の下前頭回の
賦活を認めている. しかし，この右下前頭回の賦活の 程度は言語機能の回復の程度とは関連していなかっ た。一方，左の下前頭回周囲に賦活を認めた 2 例では 失語からの回復が最も良好であった。これらの結果か ら Rosen $5^{23)}$ も左半球内の損傷部位周辺の機能保持 ないし回復が一次的に重要であると考えており，右半 球内の対照領域の賦活はむしろ左前頭部の損傷に伴う 一種の抑制・調節障害を反映した異常反応なのではな 
Vol. 42 No. 2, 2001. 4

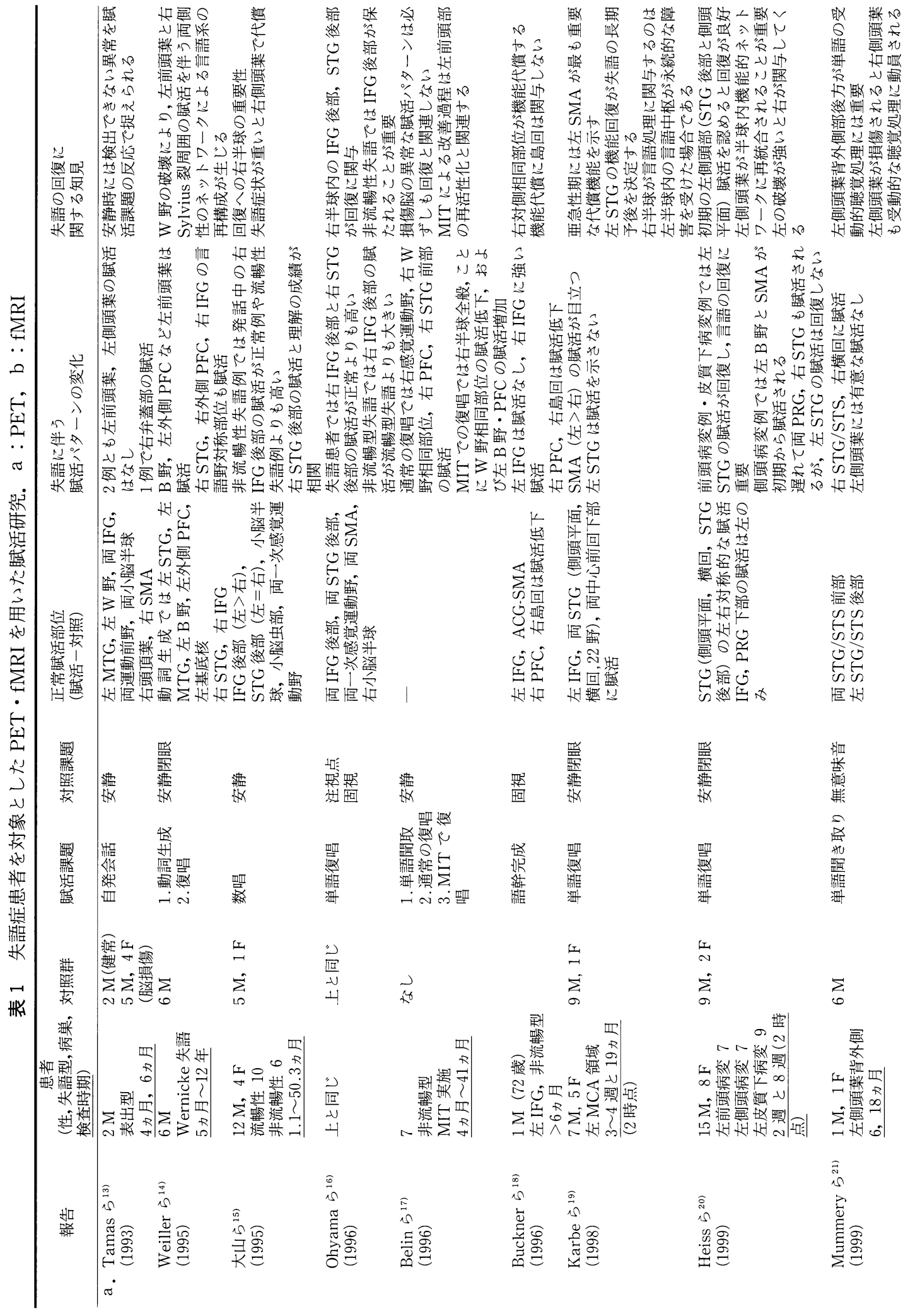




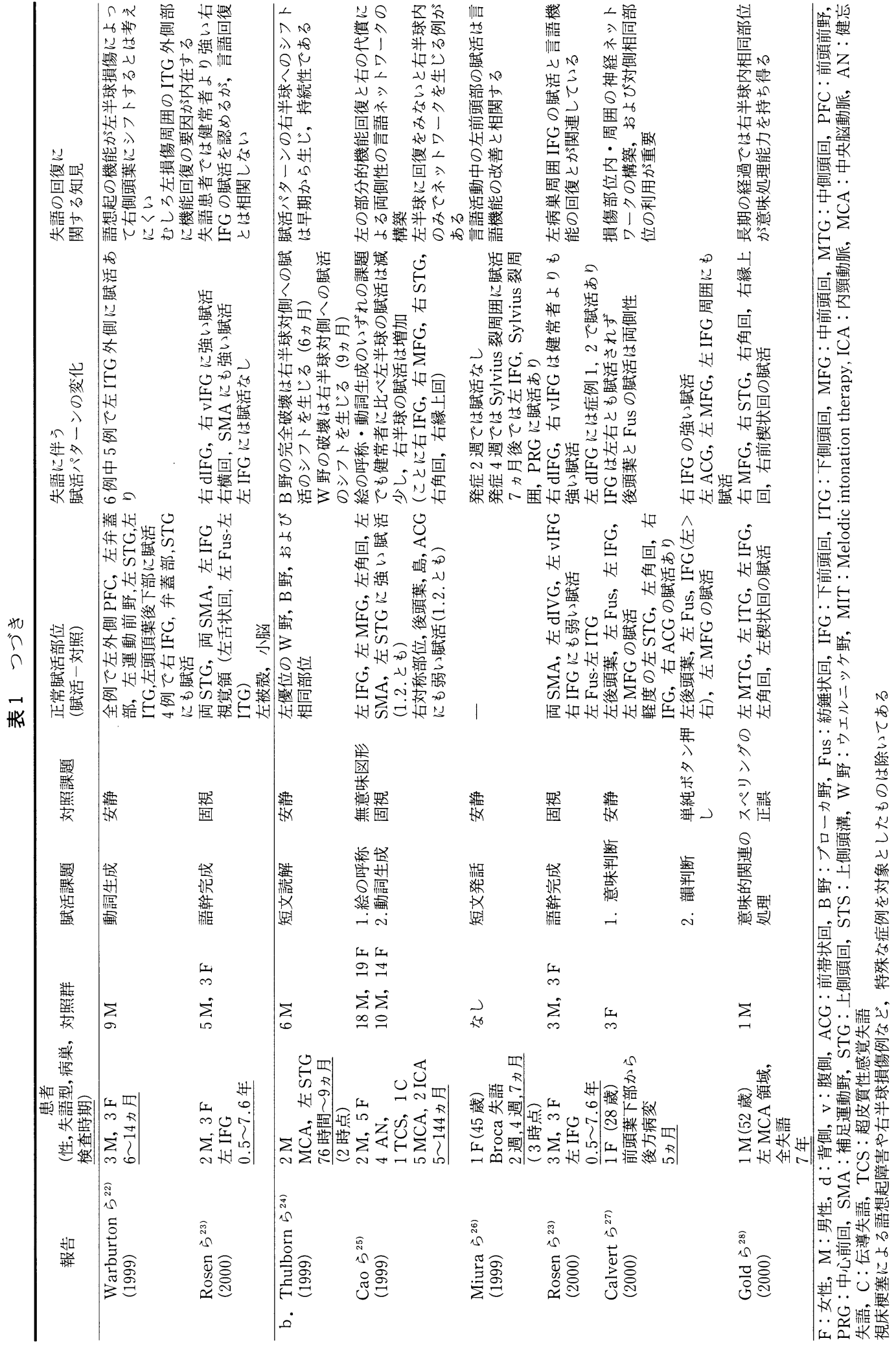


いかと想定している。しかし，それでもな抢，彼らは 右下前頭回が言語活動に関与する可能性を否定してお らず，言語的回復と脳活動とをさらに経時的に検討す ることで, 右半球の言語機能への貢献をみていくべき だとしている.事実, 最近 Gold ら ${ }^{28}$ は課題の性質が異 なるものの, 発症から 7 年後の長期経過を経た段階の 失語症患者の 1 例に fMRI を施行し, 右半球内言語領 野相同部位に賦活がシフトしていることを見出してい る.

\section{おわりに}

以上, 失語症の言語機能の回復と脳血流に関するわ れわれの 2 つの相補的研究を示し, さらに, 近年の脳 賦活機能画像研究の結果を紹介した。これらの知見を もとに現時点での失語症の回復を脳機能画像の観点か らまとめると以下のようになると思われる。

1. 失語症の回復においては左右両半球を含む機能 的ネットワークの再構築が必要である.

2 . 左右両半球は失語症の機能回復に異なる役割を 果たしている.

3. 発症から早期の段階では, 失語症の回復には左 半球内の機能的改善が重要である.

4. 右半球は失語症の回復に重要な役割を演じてい ると思われるが, その代償機構は長期の経過で遅れて 動員されてくる.

5. 右半球による代償機構は不完全である.

すでに Rosen ら ${ }^{23)}$ や Cao ら ${ }^{25)}$ の報告でも明らかな ように, 失語症の回復においてどの程度右半球内に賦 活を認めるかはかなりの個人差がある.したがって, 今後, 失語症の回復における右半球の役割を脳機能画 像の立場から検討して行く場合, 1 例 1 例の差異をて いねいにみていくこと, 何らかの形で病前の半球優位 性の個人差を評価することなどが重要であろう。さら に, 回復過程での左右半球における賦活パ夕ーンを長 期にわたって経時的にみていくことが重要である。そ の意味では, SPECT は比較的簡便に実施でき, 繰り返 し評価するのには優れている.また, SPECT でも従来 の ROI を設定して CBF を定量するのみならず, 最近 はSPM (Statistical Parametric Mapping) を用い た画像解析も可能となってきている. 今後, 失語症の 回復過程に扔ける左右半球の役割を含めて, 脳損傷例 の経時的臨床研究を行うには有用な手法であろう。

\section{文献}

1) Kertesz, A. : Neurobiological aspects of recovery from aphasia in stroke. Int Rehabil Med,
6:122-127, 1984.

2) Gainotti, G. : The riddle of the right hemisphere's contribution to the recovery of language. Eur J Disord Communication, 28:227-246, 1993.

3) Selnes, O. A. : Recovery from aphasia : Activating the "right" hemisphere. Ann Neurol, 45 : 419-420, 1999.

4）佐野洋子, 小島知幸, 加藤正弘 : 失語症状の病巣 別回復経過の検討. 失語症研究, $20: 311-318$, 2000 .

5) Naeser, M.A., Palumbo, C.L., Prete, M.N., et al.: Visible changes in lesion borders on CT scan after five years poststroke, and long-term recovery in aphasia. Brain Lang, 62 : 1-28, 1998.

6) Mimura, M., Kato, M., Kato, M., et al. : Prospective and retrospective studies of recovery in aphasia: Changes in cerebral blood flow and language functions. Brain, 121:2083-2094, 1998.

7) Matsuda, H., Tsuji, S., Shuke, N., et al. : Quantitative approach to technetium-99 m hexamethylpropylene amine oxime. Eur J Nucl Med, 19 : 195-200, 1992.

8) Matsuda, H., Tsuji, S., Shuke, N., et al. : Noninvasive measurements of ROI cerebral blood flow using technetium-99 m hexamethylpropylene amine oxime. Eur J Nucl Med, 20 : 391-401, 1993.

9) Damasio, H., Damasio, A.R. : Lesion Analysis in Neuropsychology, Oxford University Press, Oxford, 1989.

10) Heiss, W.D., Kessler, J., Karbe, H., et al. : Cerebral glucose metabolism as a predictor of recovery from aphasia in ischemic stroke. Arch Neurol, 50:958-964, 1993.

11）横山絵里子, 長田 乾, 上村和夫：脳梗塞による 失語症の言語機能と局所脳血流の相関.神経進歩, $41: 325-342,1997$.

12) Moore, W.H., Weidner, W.E. : Dichotic word perception of aphasic and normal subjects. Percept Motor Skill, 40:379-386, 1975.

13) Tamas, L.B., Shibasaki, T., Horikoshi, S., et al.: General activation of cerebral metabolism with speech: A PET study. Int J Psychophysiol, 14 : 199-208, 1993. 
14) Weiller, C., Isensee, C., Rijntjes, M., et al. : Recovery from Wernicke's aphasia: A positron emission tomographic study. Ann Neurol, 37 : 723-732, 1995.

15）大山雅史, 千田道雄, 北村 伸, 他: 失語症にお ける発語課題中の非優位半球の局所血流の変化 一PET activation study による検討一。臨床神 経，35：865-872， 1995.

16) Ohyama, M., Senda, M., Kitamura, S., et al. : Role of the nondominant hemisphere and undamaged area during word repetition in poststroke aphasics : A PET activation study. Stroke, $27:$ 897-903, 1996.

17) Belin, P., Eeckhout, V., Zilbovicius, M., et al. : Recovery from nonfluent aphasia after melodic intonation therapy : A PET study. Neurology, 47 : 1504-1511, 1996.

18) Buckner, R.L., Corbetta, M., Schatz, J., et al. : Preserved speech abilities and compensation following prefrontal damage. Proc Natl Acad Sci USA, 93 : 1249-1253, 1996.

19) Karbe, H., Thiel, A., Weber-Luxenburger, G., et al. : Brain plasticity in poststroke aphasia : What is the contribution of the right hemisphere? Brain Lang, 64 : 215-230, 1998.

20) Heiss, W.D., Kessler, J., Thiel, A., et al. : Differential capacity of left and right hemispheric areas for compensation of poststroke aphasia. Ann Neurol, 45：430-438, 1999.

21) Mummery, C.J., Ashburner, J., Scott, S.K., et al.: Functional neuroimaging of speech perception in six normal and two aphasic subjects. J Accoust Soc Am, 106 : 449-457, 1999.
22) Warburton, E., Price, C.J., Swinburn, K., et al.: Mechanisms of recovery from aphasia: Evidence from positron emission tomography studies. J Neurol Neurosurg Psychiatry, 66 : 155-161, 1999.

23) Rosen, H.J., Petersen, S.E., Linenweber, M.R., et al.: Neural correlates of recovery from aphasia after damage to left inferior frontal cortex. Neurology, 55:1883-1894, 2000.

24) Thulborn, K.R., Carpenter, P., Just, M.A.: Plasticity of language-related brain function during recovery from stroke. Stroke, 30:749-754, 1999.

25) Cao, Y., Vikingstad, E.M., George, K.P., et al.: Cortical language activation in stroke patients recovering from aphasia with functional MRI. Stroke, 30 : 2331-2340, 1999.

26) Miura, K., Nakamura, Y., Miura, F., et al.: Functional magnetic resonance imaging to word generation task in a patient with Broca's aphasia. J Neurol, 246 : 939-942, 1999.

27) Calvert, G.A., Brammer, M.J., Morris, R.G., et al. : Using fMRI to study recovery from acquired dysphasia. Brain Lang, $71: 391-399$, 2000.

28) Gold, B.T., Kertesz, A. : Right hemisphere semantic processing of visual words in an aphasic patient: An fMRI study. Brain Lang, $73: 456-465,2000$.

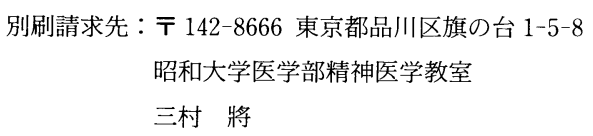

